\title{
Hematological and histological effect of fractionated neem leaf extract in healthy Wistar rats
}

\author{
David Chibuike Ikwuka ${ }^{1,2 *}$ iD, Ed Nwobodo ${ }^{2}$, Bond U. Anyaehie ${ }^{1}$, Emmanuel I. Umegbolu ${ }^{3}$ \\ 1. Department of Physiology, College of Medicine, University of Nigeria, Enugu, Nigeria \\ 2. Department of Human Physiology, Faculty of Basic Medical Sciences, Nnamdi Azikiwe University, Nnewi, Nigeria \\ 3. Department of General Outpatient, District Hospital Awgu, Enugu State, Nigeria
}

\begin{abstract}
Introduction: In recent years, the growing research towards new drugs has been targeted on plant-based drugs, and Neem (Azadirachta indica) is one of the plants that have been extensively researched for its diverse medicinal properties. The study aimed to determine the effects of neem on the hematological parameters (total white blood cells, neutrophil, monocyte and eosinophil counts) and histology of some organs of rats.
\end{abstract}

Methods: Fifteen healthy male Wister rats divided into control $\left(\mathrm{Nm}_{0}\right)$ and experimental groups $\left(\mathrm{Nm}_{11}\right.$ and $\left.\mathrm{Nm}_{22}\right)$. Control group $1\left(\mathrm{Nm}_{0}\right)$ was given $100 \mathrm{mg} / 200 \mathrm{~g}$ body weight of normal saline orally twice daily; experimental group 2 $\left(\mathrm{Nm}_{11}\right), 100 \mathrm{mg} / 200 \mathrm{~g}$ body weight neem extract twice daily for 11 days and experimental group $3\left(\mathrm{Nm}_{22}\right), 100 \mathrm{mg} / 200 \mathrm{~g}$ neem leaf extract twice daily for 22 days. Total number of white blood cells (WBC), lymphocytes, neutrophils, monocytes and eosinophils, packed cell volumes (PCV) and histological changes in the spleen, liver and kidneys were evaluated.

Results: There were no significant differences in mean values of the hematological parameters (total WBC; PCV; neutrophils, lymphocytes, monocytes and eosinophils). We observed the central vacuolation and accumulation of lymphocytes in the spleen, hypertrophy of the central vein in the liver and shrinking of the glomeruli and accumulation of the lymphocytes in the kidney using hematoxylin and eosin staining following prolonged administration of neem extract $\left(\mathrm{Nm}_{22}\right)$.

Conclusion: Prolonged administration of neem affected the histology of some organs of the rats more than the hematological parameters.

http://dx.doi.org/10.32598/ppj.24.4.60

\author{
Keywords: \\ Hematological; \\ Histological; \\ IRACARP®; \\ Toxicity; \\ Neem
}

\section{* Corresponding author: \\ D.C. Ikwuka \\ Email: \\ david.ikwuka.pg80911@unn.edu.ng \\ Tel: +2348037147603 \\ Received 4 December 2019; \\ Received in revised form 27 May \\ 2020; Accepted 17 June 2020}

\section{Introduction}

In recent years, the growing research toward new drug has been targeted on plants based drugs and neem (Azadirachta indica) is one of the plants that have been extensively researched for its diverse medicinal properties and potency. Neem tree is 
universally accepted worldwide as a wonder tree due to its wide range of medicinal properties and promise. It has been known and documented that the use of neem extract is potent in combating a range of clinical diseases which has led to the increase use of neem as phytotherapy for malaria (Udeinya et al., 2006; Lucantoni et al., 2010; Habluetzel et al., 2019), diabetes (Akinola et al., 2011; Dholi et al., 2011; Patil et al., 2013), cancer (Sharma et al., 2014; Patel et al., 2016; Santos et al., 2018), ulcer (Ofusori et al., 2010; Maity et al., 2014), bacterial (Prashant et al., 2007; Heyman et al., 2017), viral (Mbah et al., 2007; Ahmad et al., 2016; Urade et al., 2019), hypertensive (Peer et al., 2008), inflammatory (Naik et al., 2014; Lee et al., 2017), neurodegenerative diseases (Bamidele et al., 2013; Kandhare et al., 2017) etc. Despite the increased use of neem-based products for therapeutic and other purposes, little information on its toxicity is available as compared to its application level, this has necessitated further studies to ascertain the safety of neem compounds and extract for various applications. The present study aims to investigate the effect of IRACARP® a fractionated neem leaf extract on the hematological parameters and histology of Wister rat tissues.

\section{Materials and methods}

\section{IRACARP $\AA$ (fractionated neem leaf extract)}

IRACARP ${ }^{\circledR}$ purchased from Rocitus IJU Intl Limited Enugu, Nigeria; is a $250 \mathrm{mg}$ capsule of fractionated neem leaf extract also known as IRAB with registered US Pat No. 5,370,873 issued Dec. 6 1994. It is registered in Nigeria with NAFDAC registration number A7-0319L. Its extraction is done using neem leaves collected in Nigeria in a mixture of acetone and water (1:1 by Vol.) as described by Udeinya (1993). Residue from the bottom layer of the crude extracts is then fractionated by standard high performance liquid chromatography (Udeinya et al., 2006). The end product (IRAB) is a complex molecule (202 Daltons) with functional groups that include sodium salts of carboxylic acid and a non-aromatic dialcohol. Four capsules of IRACARP ${ }^{\circledR}(1000 \mathrm{mg})$ were dissolved in $100 \mathrm{ml}$ of ethanol and were given to the rats in $\mathrm{NM}_{11}$ and $\mathrm{NM}_{22}$ according to their different weights.

\section{Experimental animals}

The protocol for the animal study was approved by
College of Health Science Research Ethics Committee Nnamdi Azikiwe University Nnewi Campus and agrees with the experimental guidelines of the U.S. National Institute of Health $(\mathrm{NIH})$ and Institutional Animal Ethics Committee (IAEC) on the care and use of laboratory animals (070/05/2013). All efforts were used to reduce the number of rats used in the experiments. Experimental animals were 15 healthy male Wistar strain rats (Rattus norvegicus), four months of age, with average body weight of 220g. The Wistar rats were reared and maintained under standard conditions at room temperature, $12 \mathrm{~h}$ light/12h dark cycle and $70 \%$ humidity in the animal facility of the animal house of the Department of Human Physiology, Nnamdi Azikiwe University, Nnewi Campus, Nigeria.

\section{Experimental design}

The Wistar rats were randomly divided into three groups ( $\mathrm{n}=5 / \mathrm{each})$. Control group $1\left(\mathrm{Nm}_{0}\right)$, received $100 \mathrm{mg} / 200 \mathrm{~g}$ body weight normal saline orally, twice a day. Experimental group $2\left(\mathrm{Nm}_{11}\right)$, received $100 \mathrm{mg} / 200 \mathrm{~g}$ body weight neem leaf extract orally, twice a day for eleven days. Experimental group 3 $\left(\mathrm{Nm}_{22}\right)$, received $100 \mathrm{mg} / 200 \mathrm{~g}$ body weight neem leaf extract orally, twice a day for twenty-two days. Following the duration of the experimental period, the rats was anaesthetized with diethyl ether, whole blood was collected by cardiac puncture into EDTA container bottles and pieces of the spleen, liver and kidney were fixed in formaldehyde solution.

\section{Histological processing}

The fixed tissues were dehydrated, cleared using xylene, infiltrated and embedded in paraffin, before being sectioned using microtome. The sections slides were deparaffinized xylene to alcohol to water before staining with hematoxylin and eosin stain respectively. The stained section is mounted in D.P.X and dry for micrograph and interpretation.

\section{Hematological analysis}

The packed cell volume and differential white blood cell counts and white blood cell counts were determined as outlined by Schalm et al (1975).

\section{Hematocrit determination}

The packed cell volume was estimated using the method of Alexander and Griffiths (1993). Hematocrit 
Table 1: Total white blood cells (WBCs) counts $\left(10^{3} / \mathrm{mm}^{3}\right)$

\begin{tabular}{|c|c|c|c|}
\hline Specimens & & Groups & \\
\hline & $\mathrm{Nm}_{0}$ & $\mathrm{Nm}_{11}$ & $\mathrm{Nm}_{22}$ \\
\hline A & 8.7 & 8.5 & 8.7 \\
\hline B & 9.3 & 9.0 & 8.7 \\
\hline C & 9.0 & 8.9 & 9.5 \\
\hline D & 8.5 & 8.9 & 9.1 \\
\hline E & 9.0 & 8.8 & 9.2 \\
\hline Mean & 8.9 & 8.8 & 9.0 \\
\hline Common Mean & \multicolumn{2}{|c|}{8.9} & \\
\hline$p$-value & \multicolumn{3}{|c|}{0.69} \\
\hline f. ratio value & \multicolumn{3}{|c|}{0.744} \\
\hline
\end{tabular}

Normal saline twice a day $\left(\mathrm{Nm}_{0}\right)$, IRACARP ${ }^{\circledR}$ administration for 11days $\left(\mathrm{Nm}_{11}\right)$, IRACARP® administration for 22days ( $\left.\mathrm{Nm}_{22}\right)$.

Table 2: Differential WBC count (\%)

\begin{tabular}{ccccc}
\hline Groups & $\begin{array}{c}\text { Neutrophil } \\
(\%)\end{array}$ & $\begin{array}{c}\text { Lymphocyte } \\
(\%)\end{array}$ & $\begin{array}{c}\text { Monocyte } \\
(\%)\end{array}$ & $\begin{array}{c}\text { Eosinophil } \\
(\%)\end{array}$ \\
\hline $\mathbf{N m}_{0}$ & 27 & 72.2 & 0.2 & 0.6 \\
$\mathbf{N m}_{11}$ & 22.6 & 76.8 & 0.0 & 0.6 \\
$\mathbf{N m}_{22}$ & 29.4 & 67.8 & 0.8 & 2.0 \\
\hline $\begin{array}{l}\text { Normal saline twice a day } \\
\text { administration for 22days }\left(\mathrm{Nm}_{22}\right) .\end{array}$
\end{tabular}

capillary tubes filled by capillary action to mark with whole blood and the bottom end of the tube were sealed with plasticine. The tubes were centrifuged for 5min using DM1424 hematocrit centrifuge (Scilogex 1275 Cromwell Avenue, C-6 Rocky Hill). The percentage cell volume was read by sliding the tube along the hematocrit reader (Scilogex 1275 Cromwell Avenue, C-6 Rocky Hill) until the meniscus of the plasma intersects the $100 \%$ line.

\section{Hemoglobin estimation}

Cyamethemoglobin (Drabkin) method (Alexander and Griffiths, 1993) of hemoglobin estimation was used. The 20ul of EDTA anticoagulated whole blood was added to $5 \mathrm{ml}$ of Drabkin reagent mixed and incubated for $5 \mathrm{~min}$ at room temperature for the colour to develop. The absorbance was read against reagent blank at $540 \mathrm{~nm}$ using optima SP-300 spectrophotometer (PT. Maju Mapan Mandiri Idah Pratama).

\section{Differential leucocyte count}

Differential leucocyte count was performed on Leishman's stained thin blood film and read microscopically using immersion oil objective lens (100x magnifications) and a differential manual counter. The different white cells were counted and expressed in cell/l.

\section{Statistical analysis}

Data collected were analyzed as descriptive statistics of means and inferential statistics of ANOVA (oneway ANOVA) using MaxStat (version 3.60) statistical software. A $P$-value of $\leq 0.05$ was considered significant.

\section{Results}

Effect of IRACARP ${ }^{\circledR}$ administration on total number of white blood cells (WBCs)

Table 1 shows total WBCs $\left(10^{3} / \mathrm{mm}^{3}\right)$ of the animals. ANOVA analysis revealed that WBC number was not different between groups $(\mathrm{F}=0.74, P=0.5)$

\section{Effect of IRACARP $\AA$ administration on WBC differential counts}

As shown in Table 2, administration of IRACARP $\AA$ over 11days and 22days period caused no significant change in the neutrophil $(F=0.81, \quad P=0.47)$, lymphocyte $(F=0.96, P=0.41)$, monocyte $(F=1.86$, $P=0.20)$ and eosinophil $(\mathrm{F}=0.45, P=0.65)$ numbers (\%). 
Table 3: Packed cell volumes (PCVs) (\%)

\begin{tabular}{cccc}
\hline Specimens & Groups & \\
\hline A & $\mathbf{N m}_{\mathbf{0}}$ & $\mathbf{N m}_{\mathbf{1 1}}$ & $\mathbf{N m}_{\mathbf{2 2}}$ \\
\hline B & 40 & 33 & 35 \\
\hline C & 42 & 46 & 41 \\
\hline D & 41 & 43 & 44 \\
\hline E & 40 & 41 & 40 \\
\hline Mean & 41 & 41 & 40 \\
\hline Common Mean & $\mathbf{4 0 . 8}$ & $\mathbf{4 0 . 8}$ & $\mathbf{4 0}$ \\
\hline p-value & & $\mathbf{4 0 . 5}$ & \\
\hline f-ratio value & & $\mathbf{0 . 9 1}$ & \\
\hline
\end{tabular}

Normal saline twice a day $\left(\mathrm{Nm}_{0}\right)$, IRACARP® administration for 11 days $\left(\mathrm{Nm}_{11}\right)$, IRACARP® administration for 22days $\left(\mathrm{Nm}_{22}\right)$.

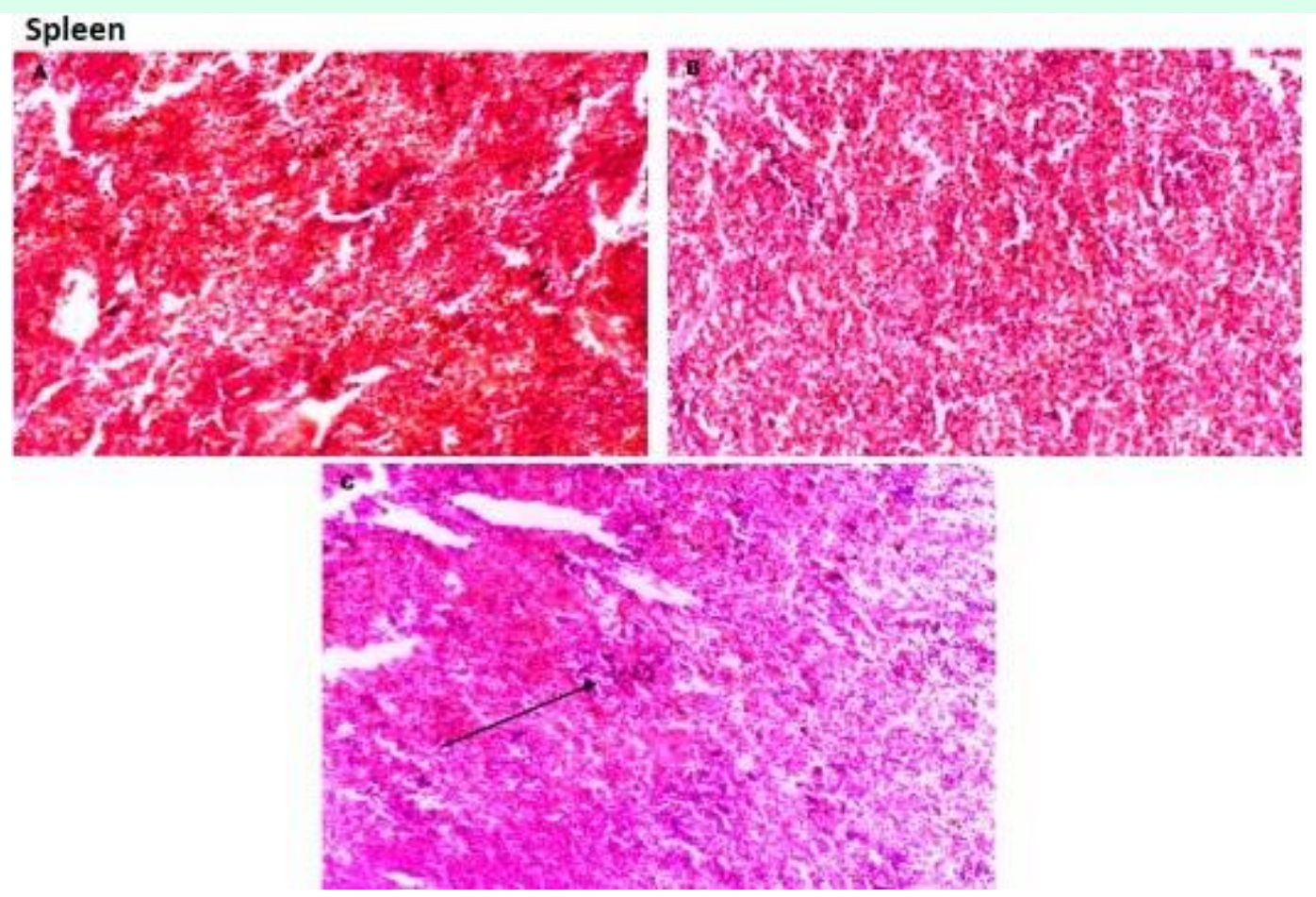

Fig.1. Shows the histopathological changes in rat spleen following long-term administration of IRACARP $®$. Cross-sectional view of the spleen to represent the cellular outline and architecture. A. Nmo without IRACARP® administration (Control) B. $\mathrm{Nm}_{11}$ IRACARP® for 11 days C. $\mathrm{Nm}_{22}$ IRACARP® for 22 days.

\section{Effect of IRACARP ${ }^{\circledR}$ administration on packed cell volumes (PCV)}

Table 3 shows packed cell volumes (in \%) of the animals. There was no significant difference between the three groups $(F=0.09, P=0.91)$.

\section{Effect of IRACARP® administration on spleen}

The histoarchitecture of the spleen sections stained with hematoxylin and eosin (H\&E) are shown in Figure 2. The photomicrograph of $\mathrm{Nm}_{0}$ (control) and $\mathrm{Nm}_{11}$ groups showed normal appearance. In $\mathrm{Nm}_{22}$ group cytoplasm vacuolation and mild accumulation of lymphocytes were observed.

Effect of IRACARP ${ }^{\circledR}$ administration on liver tissue The histoarchitecture of the liver sections stained with $\mathrm{H} \& \mathrm{E}$ are shown in Figure 2. The photomicrograph of $\mathrm{Nm}_{0}$ and $\mathrm{Nm}_{11}$ groups showed normal appearance. In $\mathrm{Nm}_{22}$ group slightly hypertrophied central vein were observed.

\section{Effect of IRACARP $\AA$ administration on kidney}

The histoarchitecture of the kidney sections stained with H\&E are shown in Figure 3. The photomicrograph of $\mathrm{Nm}_{0}$ and $\mathrm{Nm}_{11}$ groups showed 

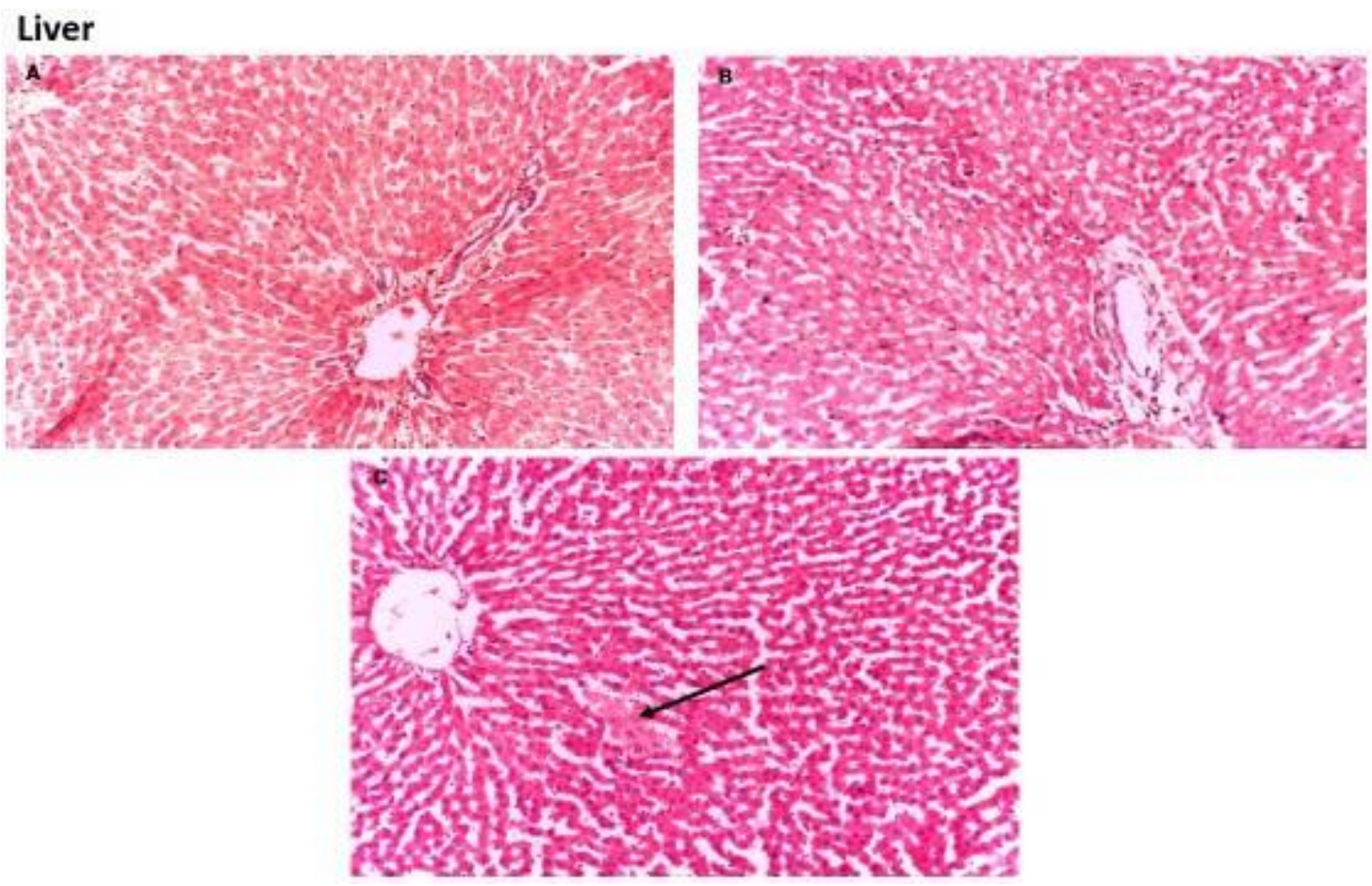

Fig.2. Histopathological changes in rat liver following long-term administration of IRACARP®. Cross-sectional view of the liver to represent the cellular outline and architecture. A. $\mathrm{Nm}_{0}$ without IRACARP® administration (Control) B. $\mathrm{Nm}_{11}$ IRACARP® for 11 days $C$. $\mathrm{Nm}_{22}$ IRACARP® for 22 days.

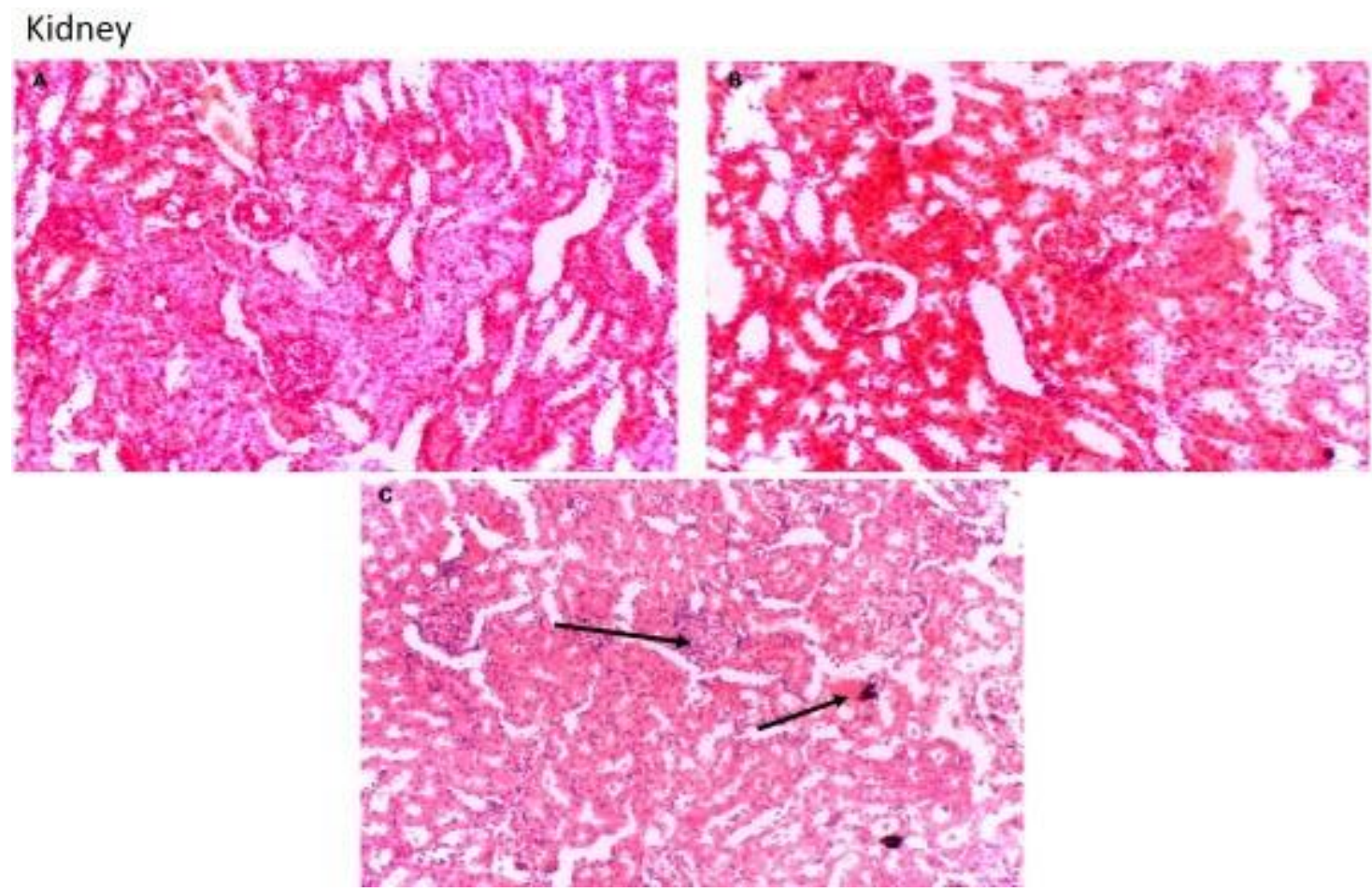

Fig.3. Histopathological changes in rat kidney following long-term administration of IRACARP®. Cross-sectional view of the kidney to represent the cellular outline and architecture. A. Nmo without IRACARP® administration (Control) B. Nm 11 IRACARP® for 11 days $\mathrm{C} . \mathrm{Nm}_{22}$ IRACARP® for 22 days.

normal appearance. In $\mathrm{Nm}_{22}$ group, shrunken glomeruli with slight aggregation of lymphocytes were observed.

\section{Discussion}

Toxicity studies in animals are often used to evaluate potential health risk posed by adverse effects of plant 
extract to humans (Ashafa et al., 2012). The present study evaluated the effects of fractionated neem leaf extract derivative IRACARP® on hematological parameters and histology of the spleen, liver and kidney of normal male Wister rats. Hematological parameters are important in diagnosing the structural and functional status of animals exposed to a substance because blood parameters are highly sensitive to environmental and physiological changes and health conditions (Esonu et al., 2006; Kwawukume et al., 2013).

WBCs are involved in the regulation of immunological function and their numbers increase as a protective response to stress (Schalm et al., 1975). The data presented in this report, showed that short term and long term treatment with IRACARP ${ }^{\circledR}$ caused no significant change in the total white blood cell count. This finding is contrary to the result obtained from previous studies who reported that neem extract increased the total WBC following administration of substances that were toxic to animal hematology (Anokwuru et al., 2011; Kapinga et al., 2018; Kaur et al., 2019). However, Ashafa et al. (2012) observed that neem extract significantly reduced WBC in wistar rats.

Evaluation of WBC differential count are important in identifying the specific effect the administered substance could have on the body immune system, as increase in any of the leucocyte could be an indicator of an immunological reaction to an infection or allergy. In evaluating the effect of neem leaf extract on neutrophil count, neutrophil counts were slightly higher in the control group $\mathrm{Nm}_{0}(27 \%)$ than the treatment groups $\mathrm{Nm}_{11}$ and $\mathrm{Nm}_{22} \quad(22.5 \%$ and $25.45 \%)$; however, the figures were not statistically significant and were within the normal range. Physiologically, neutrophils help heal damaged tissues and resolve infections and its level increase naturally in response to infections, injuries and other types of stress. In rats, they are important during bacterial infections as they act as macrophages and IRACARP ® slightly suppresses neutrophil level. This finding supports the reports that have shown, neem decreases neutrophil count (heterophil in birds) in rabbits (Ogbuewu et al., 2010), birds (Kwawukume et al., 2013) and fish (Kapinga et al., 2018).

Lymphocyte counts in treated groups were higher when compared to the control group but this increase, which may be attributed to neem leaf extract were not statistically significant and still within the normal range of $70-99 \%$. This finding supports the reports that have shown, neem increases lymphocytic proliferative responses in experimental mice, rat and bird (Kwawukume et al., Njiro et al., 1999; Kapinga et al., 2018). There was no significant difference in monocyte count of control and treatment groups following short term and long term administration of neem leaf extract as the values were still within range of normal values of $0-6 \%$ for Monocyte. There was also no significant difference between eosinophil counts of control and treatment groups respectively.

In evaluating the effect of neem leaf extract on packed cell volume, there was no significant difference in the mean values of the packed cell volume $(40.8 \%, 40.8 \%$ and $40 \%)$ following short and long term administration of IRACARP $\AA$, the values fall within the normal range of $36 \%$ to $46 \%$ for PCV. This finding is contrary to the reports from earlier studies done in other animals which stated that neem reduces the packed cell volume (Saravanan et al., 2011; Oloruntola et al., 2019).

The histopathological analysis of the spleen were normal for of $\mathrm{Nm}_{0}$ and $\mathrm{Nm}_{11}$, however, cytoplasmic vacuolation and mild accumulation of lymphocytes in the lymphoid tissue of $\mathrm{Nm}_{22}$ were observed. The cytoplasmic vacuolation in splenic cells is mainly a consequence of considerable disturbances in lipid inclusions and fat metabolism occurring under pathological changes (Banhawy, 1993). The histopathological analysis of the liver were normal for $\mathrm{Nm}_{0}$ and $\mathrm{Nm}_{11}$. However, the central vein of the liver in $\mathrm{Nm}_{22}$ is slightly hypertrophied. This hypertrophic response is indicative of billary obstruction which may be due to chronic exposure of the liver to neem leaf extract (Kim et al., 2011). The histopathological investigation of the kidney were normal for. However, some shrunken glomeruli with slight accumulation of lymphocytes were observed in $\mathrm{Nm}_{22}$. This alteration in the structure of the glomeruli is indicative of decreased renal perfusion which may be alluded to a chronic administration of neem leaf extract (Basile et al., 2011).

\section{Conclusion}

Hematological parameters of the Wister rats administered with neem leaf extract for shorter and longer durations did not show any significant 
differences with those of the control. However, histopathological changes were observed in the spleen, liver and kidneys following chronic administration of neem leaf extract. Therefore, prolonged administration of neem leaf extract in animal model cause histopathological changes in spleen, liver and kidney. A human model of this study could be designed using full blood count and ultrasound monitoring of the internal organs to determine if the same changes seen in the rats would also be seen in humans.

\section{Acknowledgments}

We thank the chief technologist Mr. Onah Sylvester, Mrs. Elosiobah Nwanneka and entire staff of the Department of Human Physiology Laboratory, Nnamdi Azikiwe University Nnewi, for their support through the laboratory process. Funding for this research was provided mainly by the contributions from the authors and some support from the Department of Human Physiology, Nnamdi Azikiwe University Nnewi Campus, Nnewi, Nigeria.

\section{Conflict of interest}

The authors declare that no conflicts of interest.

\section{References}

Ahmad A, Javed MR, Rao AQ, Husnain T. Designing and screening of universal drug from neem (Azadirachta indica) and standard drug chemicals against influenza virus nucleoprotein. BMC Complement Altern Med 2016; 16:

1-8. https://doi.org/10.1186/s12906-016-1469-2

Akinola OB, Omotoso OG, Dosumu OO, Akinola OS, Olotufore F. Diabetes-Induced prefrontal Nissl substance deficit and the effects of Neem-Bitter leaf extract treatment. Int J Morphol 2011; 29: 850-6. https://doi.org/10.4067/S0717-95022011000300031

Alexander RR, Griffiths JM. Basic Biochemical Methods. 2nd Ed. New York: John Wiley and Sons, 1993.

Anokwuru CP, Ezekiel CN, Alabi OA, Shallie PD, Haruna MT. Ameliorative effects of ethanolic neem extract on dietary aflatoxin induced hematological damage and hepatotoxicity in mice. Asian J Med Sci 2011; 3: 254-60.

Ashafa AO, Orekoya, LO, Yakubu MT. Toxicity profile of ethanolic extract of Azadirachta indica stem bark in male Wistar rats. Asian Pac J Trop Biomed 2012; 2: 811-7.https://doi.org/10.1016/S2221-1691(12)60234-2

Bamidele FP, John AA, Bukoye OE, Hannah AO. A study of some effects of aqueous extract of neem (Azadirachta indica) leaves on the lead acetate induced neurotoxicity in the superficial layers of superior colliculus of adult wistar rats (Rattus norvegicus). J Pharm Res 2013; 4:
217-31. https://doi.org/10.9734/BJPR/2013/2344

Basile DP, Anderson MD, Sutton TA. Pathophysiology of acute kidney injury. Compr Physiol 2011; 2: 1303-53. https://doi.org/10.1002/cphy.c110041

Dholi SK, Ramakrishna R, Mankala SK, Nagappan K. In vivo antidiabetic evaluation of neem leaf extract in Alloxan induced rats. J Appl Pharmaceut Sci 2011; 1: 100-5.

Banhawy El. Histopathological studies on the effect of the anticoagulant rodenticide "Brodifacoum" on the liver of rat. J Egypt Ger Soc Zool 1993; 12: 185-227.

Esonu O, Okoli C, Opara M, Obikaonu O, Udedibie C, Iheshiulor M. Physiological responses of laying birds to Neem (Azadirachta indica) leaf meal based diets, body weight, organ characteristics and hematology. Online $\mathrm{J}$ Health Allied Sci 2006; 5.

Habluetzel A, Pinto B, Tapanelli S, Nkouangang J, Saviozzi M, Chianese G, et al. Effects of Azadirachtaindicaseed kernel extracts on early erythrocyticschizogony of Plasmodium berghei and pro inflammatory response in inbred mice. Malar J 2019; 18: 1-9. https://doi.org/10.1186/s12936-019-2671-8

Heyman L, Hour-Haddad Y, Heyman SN, Ginsburg I, Gleitman Y, Feuerstein O. Combined antioxidant effects of Neem extract, bacteria, red blood cells and lysozyme: possible relation to periodontal disease. BMC Complement Altern Med 2017; 17: 399-407. https://doi.org/10.1186/s12906-017-1900-3

Kandhare AD, Mukherjee AA, Bodhankar SL. Neuroprotective effect of Azadirachta indica standardized extract in partial sciatic nerve injury in rats: evidence from anti-inflammatory, antioxidant and antiapoptotic studies. Excli J 2017; 16: 546-65.

Kapinga IB, Limbu SM, Madalla NA, Kimaro WH, Tamatamah RA. Aspilia mossambicensis and Azadirachta indica medicinal leaf powders modulate physiological parameters of Nile tilapia (Oreochromis niloticus). Int $J$ Vet Med Sci 2018; 6: 31-8. https://doi.org/10.1016/j.ijvsm.2018.03.003

Kaur Y, Dhawan A, Holeyappa SA, Thammegowda NB. Hematological responses of common carp Cyprinus carpio administered with Neem (Azadirachta indica) leaf extraction. Indian J Anim Res 2019; 53: 161-7. https://doi.org/10.18805/ijar.B-3494

Kim RD, Kim JS, Behrns KE. Liver regeneration and the atrophy-hypertrophy complex. Semin Intervent Radiol 2011; 37-47. https://doi.org/10.1007/978-1-84882-1224_6

Kwawukume AA, Aning KG, Awuni JA, Otsyina $H$, Awumbila B. The effects of Azadirachta indica (Neem) leaf extract on white blood cell count and the immune response of chickens vaccinated with newcastle disease vaccine. Int J Curr Sci 2013; 7: 23-31.

Lee JW, Ryu HW, Park SY, Park HA, Kwon OK, Yuk HJ, et al. Protective effects of neem (Azadirachta indica A. Juss.) leaf extract against cigarette smoke-and lipopolysaccharide-induced pulmonary inflammation. Int J Mol Med 2017; 40: 1932-40. https://doi.org/10.3892/ ijmm.2017.3178 
Lucantoni L, Yerbanga RS, Lupidi G, Pasqualini L, Esposito F, Habluetzel A. Transmission blocking activity of a standardized neem (Azadirachta indica) seed extract on the rodent malaria parasite Plasmodium berghei in its vector Anopheles stephensi. Malar J 2010; 9: 66. https://doi.org/10.1186/1475-2875-9-66

Maity P, Biswas K, Chattopadhyay I, Banerjee RK, Bandyopadhyay U. The use of Neem for controlling gastric hyperacidity and ulcer. Phytother Res 2014; 23 : 747-55. https://doi.org/10.1002/ptr.2721

Mbah AU, Udeinya IJ, Shu EN, Chijioke CP, Nubila T, Udeinya $F$, et al. Fractionated neem leaf extract is safe and increase CD4+ cell levels in HIV/AIDS patients. Am J Ther 2007; 14: 369-74. https://doi.org/10.1097/ MJT.0b013e3180a72199

Naik MR, Bhattacharya A, Behera R, Agrawal D, Dehury S, Kumar S. Study of anti-inflammatory effect of neem seed oil (Azadirachtaindica) on infected albino rats. J Health Res Rev 2014; 1: 66. https://doi.org/10.4103/ 2394-2010.153880

Njiro SM, Kofi-Tsekpo MW. Effect of an aqueous extract of Azadirachta indica on the immune response in mice. Onderstepoort J Vet Res 1999; 66: 59-62.

Ofusori DA, Falana BA, Ofusori AE, Abayomi TA, Ajayi SA, Ojo GB. Gastroprotective effect of aqueous extract of neem Azadirachta indica on induced gastric lesion in rats. Int J Biol Med Res 2010; 1: 219-22.

Ogbuewu IP, Okoli IC, lloeje MU. Evaluation of toxicological effects of leaf meal of an ethnomedicinal plant-neem on blood chemistry of puberal chinchilla rabbit does. Rep Opinion 2010; 2: 29-34

Oloruntola OD, Agbede JO, Ayodele SO, Oloruntola DA. Neem, pawpaw and bamboo leaf meal dietary supplementation in broiler chickens: effect on performance and health status. J Food Biochem 2019; 43: e12723 https://doi.org/10.1111/jfbc.12723

Patel SM, Venkata KC, Bhattacharyya P, Sethi G, Bishayee A. Potential of neem (Azadirachta indica L.) for prevention and treatment of oncologic diseases. Sem Cancer Biol 2016. https://doi.org/10.1016/j.semcancer. 2016.03.002

Patil P, Patil S, Mane A, Verma S. Antidiabetic activity of alcoholic extract of neem (Azadirachtaindica) root bark. Nat J Physiol Pharm Pharmacol 2013; 3: 142. https://doi.org/10.5455/njppp.2013.3.134-138

Peer PA, Trivedi PC, Nigade PB, Ghaisas MM, Deshpande AD. Cardioprotective effect of Azadirachta indica A. juss. On isoprenaline induced myocardial infarction in rats. Int J Cardiol 2008; 126: 123-6. https://doi.org/ 10.1016/j.ijcard.2007.01.108

Prashant GM, Chandu GN, Murulikrishna KS, Shafiulla MD. The effect of mango and neem extract on four organisms causing dental caries: Streptococcus Mutans, streptococcus salivavius, Streptococcus Mitis, and streptococcus sanguis: an in vitro study. Indian J Dent Res 2007; 18: 148. https://doi.org/10.4103/ 0970-9290.35822

Santos KS, Barbosa AM, Freitas V, Muniz AV, Mendonça $\mathrm{MC}$, Calhelha RC, et al. Antiproliferative activity of Neem leaf extracts bbtained by a sequential pressurized liquid extraction. Pharm 2018; 11: 76. https://doi.org/10.3390/ph11030076

Saravanan M, Ramesh M, Malarvizhi A, Petkam R. Toxicity of neem leaf extracts (Azadirachtina indica A. Juss) on some haematological, ionoregulatory, biochemical and enzymological parameters of Indian major carp, Cirrhinus mrigala. J Trop for Environ 2011; 1. https://doi.org/10.31357/jtfe.v1i1.80

Schalm OW, Jain NC, Caroll EJ. Veterinary Hematology. 3rd Edn., Lea and Fabiger, Philadephia, 1975, pp. 15218.

Sharma C, Vas AJ, Goala P, Gheewala TM, Rizvi TA, Hussain A. EthanolicNeem (Azadirachtaindica) leaf extract prevents growth of MCF-7 and HeLa cells and potentiates the therapeutic index of Cisplatin. J Oncol 2014. https://doi.org/10.1155/2014/321754

Udeinya IJ, Brown N, Shu EN, Udeinya FI, Quakeyie I. Fractions of an antimalarial neem-leaf extract have activities superior to chloroquine and are gametocytocidal. Ann Trop Med Parasitol 2006; 100: 17-22. https://doi.org/10.1179/136485906X78508

Udeinya IJ. Anti- malarial activity of Nigerian neem leaves. Trans Royal Soc Trop Med Hyg 1993; 87: 471. https://doi.org/10.1016/0035-9203(93)90042-O

Urade PK, Pimpalshende SV. Neem extract: a potential herbal remedy for treating HIV. EJBPS 2019; 6: 193202. 